\title{
A reply to Professor Dixon's comments on the Productivity Commission's modelling of automotive assistance
}

[This paper was published in Economic Papers, vol. 28 no. 12009 pp. 19-24, in response to Professor Dixon's comments published in the same issue.]

\section{Lisa Gropp, Patrick Jomini and John Salerian ${ }^{1}$}

In his article, Professor Peter Dixon largely reiterates arguments made in earlier papers (Dixon and Rimmer 2008 and Dixon 2008), which formed part of consultancy reports, including for Lateral Economics (LE 2008). The Commission has responded to his criticisms in two technical supplements (PC 2008b, 2008c) to its June 2008 report Modelling Economy-wide Effects of Future Automotive Assistance (PC 2008a), ${ }^{2}$ and this reply draws liberally from them.

In all economic modelling, simulation results are sensitive to model assumptions. For its modelling of assistance options for the automotive industry, the Commission employed a number of strategies to enhance and test the robustness of the results.

1. To start with, the MMRF model, developed by the Centre of Policy Studies (CoPS) at Monash University, was used because it is relatively welldocumented, with a proven track record, and provides results at the jurisdictional level. The short time-frame for the study precluded dynamic modelling which requires forecasting a base-case scenario.

2. Assumptions and preliminary results were reviewed by a panel of expert referees and discussed with them at a workshop. ${ }^{3}$ Their comments were taken into account in preparing the report.

\footnotetext{
1 Productivity Commission, Melbourne.

2 On 14 April 2008 the Commission was asked by the Assistant Treasurer to model various assistance options for the Review of Australia's Automotive Industry. The Commission's report was delivered to Government on 30 May 2008, as requested.

3 The expert panel comprised David Pearce (Centre for International Economics), Chris Murphy, Director of Econtech), and Philip Adams (Director of CoPS). Their written reports, which were based on preliminary results presented at a workshop, are summarised in the Commission's report (PC 2008a) and available in full on the Commission's website (www.pc.gov.au).
} 
3. A number of sensitivity simulations to illustrate the consequences of adopting various assumptions were undertaken and published in the report. Anyone preferring different assumptions from those used by the Commission in its 'reference' scenario can draw upon these results — as, indeed, Dixon has done.

In essence, and in contrast to the Commission, Dixon argues that reducing the tariff on imported passenger motor vehicles from 10 to 5 per cent will likely reduce Australia's economic welfare, or at best generate no welfare improvement. There are several reasons for the different conclusions.

- In Dixon's assessment, the elasticity of demand for all Australian exports is assumed to be -4 compared with -10 in the Commission's reference case. More inelastic export demands generate larger adverse terms of trade effects and dampen the resource reallocation effects in response to tariff reductions in the model. Sensitivity analysis undertaken by the Commission showed that using an elasticity of -5 roughly doubles terms of trade losses.

- Dixon proposes a much smaller value for the capital-labour elasticity of substitution than the standard 0.5 for the MMRF model (used in the Commission's modelling). This dampens the resource reallocation response to relative price changes, limiting efficiency gains from tariff reductions. While the Commission did not present sensitivity analysis for this parameter in its report, subsequent modelling indicated that applying a capital-labour substitution elasticity of around 0.1, as done by Dixon, would reduce modelled gains by roughly 30 per cent.

- The Commission used a long-run closure, which allows capital to adjust in aggregate. Dixon effectively adopts a short-run model closure which holds aggregate capital fixed. As the Commission noted in its report, the long-run closure is crucial for its results. Sensitivity analysis still showed gains with a short-run closure, but they were small because terms-of-trade losses almost offset efficiency benefits from resource re-allocation.

- Related to the long-run closure and aggregate capital expansion, Dixon criticises the welfare indicator ('adjusted GNE') used by the Commission to measure income accruing to Australian residents.

In the current article and earlier papers cited above, Dixon gives additional reasons why gains from tariff reductions might be overstated in the Commission's modelling. These generally are of second-order importance, but nonetheless are germane to his conclusion. For instance, he has observed that the burden of raising taxes to maintain revenue neutrality is not fully reflected in the model, overstating the benefits of reducing tariffs. 
Taken together, Dixon's assumptions generate results which imply a sizeable optimum tariff for Australia (considerably higher than current tariff levels). However, he has incorporated a small productivity benefit (a so-called cold-shower effect) flowing from lower protection. Also, in an earlier paper, Dixon assumed that some exporters already exploit their international market power, which reduces modelled terms of trade losses. (The Commission did not incorporate either of these welfare-enhancing effects in its reference case scenario.) The upshot is that his modelled optimum tariff ends up roughly coinciding with the tariff rate currently applying to the automotive sector.

\section{The Commission's approach and assumptions}

\section{The elasticity of demand for Australia's exports}

The Commission addressed the issue of export demand elasticities at length in its report and the first technical supplement to that report (PC 2008a and 2008b). As noted earlier, Dixon adopts an elasticity of demand for all Australian exports of -4 compared with -10 used by the Commission in its reference case. The elasticity used by the Commission is consistent with values used by Murphy (2002) and implied by recent applications of the GTAP model ${ }^{4}$ by the Centre for International Economics (CIE 2002). It also lies within the range of -8 to -12 posited by Lateral Economics in a critique of the Commission's modelling (LE 2008). In essence, the Commission considered that Australia's global market power is likely to be more limited, particularly over the long term when buyers and rival suppliers have had time to adjust, than implied by the elasticity value used by Dixon.

\section{Short- or long-run model closure?}

As already noted, one of the key determinants of the magnitude of modelled economy-wide gains from reducing automotive assistance is the assumption made about the flexibility of the economy to adjust, including through the ability to expand the capital stock. The Commission adopted a standard long-run closure for its reference case. As pointed out in its technical supplement (PC 2008b), this longrun closure has been widely applied in policy analysis using comparative static computable or applied general equilibrium models. ${ }^{5}$ Under the long-run closure:

\footnotetext{
4 GTAP is a computable general equilibrium model of the world economy, coordinated by the Center for Global Trade Analysis at Purdue University.

5 Fixed labour supply, endogenous wages, fixed post-tax rates of return and an endogenous capital stock comprise the standard setting used in long-run comparative static models such as the
} 
- labour supply in the economy is fixed and wages adjust

- post-tax rates of return are fixed and the aggregate capital stock adjusts

- government consumption is tied to household consumption

- the government balance as a ratio of GDP is fixed, and a broad base tax on factor incomes (labour and capital) adjusts to maintain the government balance as a ratio of GDP

- investment is tied to the capital stock.

In this economic environment, reductions in automotive tariffs lower both the costs of production for industries in Australia and for consumption of cars by households, governments and investment (capital creation). Importantly, as automotive products are important inputs to capital formation, reductions in their price reduce the cost of creating capital: this leads to an expansion in industrial output, facilitated by an expansion of the capital stock.

Further, it should be noted that this long-run expansion in activity is not driven by the use of a comparative static model. In its report, the Commission presented a reconciliation of modelling undertaken for its 2003 inquiry into assistance for the automotive industry which used the recursive dynamic MONASH model 6 , and its 2008 modelling using MMRF. The results from the 2003 model were found to be comparable with the 2008 results when MONASH was run to simulate the full effects of tariff shocks over a longer period than modelled in the 2003 report (PC 2003).

\section{Capital-labour elasticity of substitution}

The long-run closure also interacts with a key parameter in the model - the elasticity of substitution between labour and capital. The Commission saw no reason to change the standard value of 0.5 used by the Centre of Policy Studies in its MMRF model. While this value is higher than the 0.1 which Dixon now advocates, when compared with values applied in other long-run comparative static modelling, it appears low. For example, Econtech uses an elasticity value of 0.75 , the OECD assumes values between 0.8 and 1 , and GTAP between 0.27 and 1.1.

MMRF model (Adams, Horridge and Wittwer 2002), as well as in models developed and used by Econtech, such as MM600+ (Murphy 2002).

6 MONASH is a recursive dynamic, computable general equilibrium model developed at CoPS, Monash University. 


\section{Measuring welfare change}

Real national disposable income is generally accepted as a good indicator of economy-wide welfare but the MMRF model does not directly measure it. Instead, like most other CGE models, it generates partial measures of welfare such as Gross Domestic Product (GDP), which represents the total value of final output produced in the economy in a given year. However, not all of this accrues to Australians because some of the capital stock is owned by foreigners and some after-tax income consequently accrues to foreign investors.

To overcome the limitations of relying solely on GDP as a measure of the benefits accruing to Australians from policy changes, the Commission chose 'adjusted Gross National Expenditure (GNE)' as a welfare indicator. Adjusted GNE is an indicator of the real national income accruing to Australians from the current value of production (GDP). The link between GDP and adjusted GNE is set out in box 1 . The Australian Bureau of Statistics uses a similar indicator, namely Real Net National Disposable Income (ABS 2008). Recently, Coleman (2008) has discussed the superiority of Real Gross Domestic Income over GDP as an indicator of welfare in the presence of changes to the terms of trade.

\section{Box 1 What is 'adjusted GNE'?}

GDP can be disaggregated into the income accruing to Australians and income accruing to foreign investors. Adjusted GNE is the income accruing to Australians from their work and their savings invested in Australia and abroad. It is defined as GDP less the net income paid to foreign investors (IPF). IPF is the year's return on foreigners' accumulated investments in Australia's capital stock and land, less the return to Australians from their investments abroad.

Net income paid to foreigners is recorded as an outflow in the current account:

$C A=(X-M)-I P F$

On the capital account, net foreign investment equals investment (in Australia) less domestic savings:

$\mathrm{NFI}=\mathrm{I}-\mathrm{S}_{\mathrm{d}}\left(\right.$ and $\left.\mathrm{S}_{\mathrm{d}}=\mathrm{I}-\mathrm{NFI}\right)$

As the capital and current accounts must sum to zero $(\mathrm{NFI}=-\mathrm{CA})$ :

$\mathrm{IPF}=\mathrm{NFI}+(\mathrm{X}-\mathrm{M})$

As adjusted GNE is GDP less IPF, it can be written as:

Adjusted GNE $=\mathrm{C}+\mathrm{I}+\mathrm{G}+(\mathrm{X}-\mathrm{M})-[\mathrm{NFI}+(\mathrm{X}-\mathrm{M})]=\mathrm{C}+\mathrm{G}+(\mathrm{I}-\mathrm{NFI})$

$=C+G+S_{d}$ 
Comparative static CGE models do not have a database that represents a true steady state - instead the database is calibrated on data from a particular year (in this instance 2005-06). Nor do comparative static models track the time path of adjustment. As a result, there is no explicit behavioural connection between capital and investment and saving, and assumptions must be made about the source of capital. In the absence of behavioural relationships determining domestic savings, the model applies a fixed average propensity to save. The MMRF database also reflects an assumption that the capital stock of the economy is 80 per cent domestically owned and 20 per cent foreign owned. This assumption is built into the household income equation, and is maintained in the policy deviation. Consequently, the Commission's results reflect the assumption that 80 per cent of the expanded capital stock induced by reductions in automotive assistance is owned by Australians, but does not reveal the path of capital accumulation. If instead it is assumed that all of the increase in capital stock is foreign owned, the modelled increase in income accruing to Australians would be about $\$ 200$ million (compared with $\$ 66$ million reported by Dixon) because Australians still benefit from the expansion of the economy over the longer run. This assumption essentially sets a lower bound. The increase in GDP would remain largely unchanged at about $\$ 600$ million.

\section{Other considerations}

As the Commission noted in its report, while modelling can provide useful insights, no model can give the full picture. Economic models necessarily are stylised representations of the real world - inevitably many factors lie outside the model and must be considered (and possibly modelled) separately. As noted earlier, Dixon has modelled some of these factors and the Commission discusses a number of additional considerations in its report and technical supplements. On balance, these suggest further potential net gains from scheduled reductions in automotive assistance.

- Adjustment costs incurred by displaced workers should be subtracted from estimated gains. However, the Commission judged that once-off adjustment costs were unlikely to be large for several reasons, including that assistance reductions have been signalled ahead of their implementation and phased over many years.

- Dixon argues that the modelling underestimates the deadweight cost of raising labour and capital taxes to offset lost tariff revenue. While it is true that the deadweight burden of raising income and other taxes to replace tariff revenue is likely understated, the Commission has pointed out that the modelled benefits of reducing direct subsidies of more than $\$ 500$ million per year to the industry would likewise be underestimated. 
- The modelling assumes constant returns to scale, yet the automotive industry exhibits sizeable scale economies. On the one hand, lower assistance leading to withdrawal of a car assembler could reduce sales for some components manufacturers, increasing their unit costs. On the other, withdrawal of a car assembler could increase sales for remaining assemblers, promoting cost reductions. Expansion of other industries in the economy resulting from lower car tariffs would also tend to promote exploitation of economies of scale.

- Dixon has modelled a small 'cold-shower effect' resulting from further assistance reductions. The Commission observed in its report that the scope for efficiency improvements was likely to be more limited than in the past. As the magnitude of these was speculative, the Commission did not incorporate a productivity improvement in its modelled reference case, but nonetheless felt that further efficiencies were feasible, including from more cooperative workplace relations and reduced lobbying activity.

- As the Commission noted in its report and first technical supplement, while the model imposes a uniform average export demand elasticity (as much to proxy frictions in the economy as to reflect actual market power), in reality, Australia's market power is likely to be limited for most goods and services over the longer term. Even in circumstances where Australian exporters have the potential to obtain price premiums, government intervention to control exports might not be required. For example, if goods and services are differentiated at the firm level, firms themselves will seek to maximise revenue by limiting supply. And some industry arrangements are already in place to control commodity exports to quota-restricted markets. In an earlier paper Dixon (2008) moderated the modelled terms of trade loss by assuming that some industries with market power already efficiently exploited that power, yet this possibility has not been included in his current paper. To the extent that such premiums are already being realised, a reduction in assistance to the automotive sector will lead to increased export revenues, as export prices fall by less than the reduction in costs.

- It should be further noted that the passenger motor vehicle sector in Australia is dominated by foreign-owned firms. Assistance reductions will mean that the part of the $\$ 1$ billion annual subsidy equivalent paid to the sector (from the tariff and direct subsidies) that is currently accruing to foreign share-holders, will be returned to Australian car buyers, taxpayers or users of government services. This would represent a net gain in national income (rather than simply a domestic transfer), but has not been taken into account in the modelling. 


\section{Concluding remarks}

Dixon adopts a suite of model assumptions which simultaneously limit the resource response to reduced automotive tariffs and heighten adverse terms of trade effects.

While the Commission presented results from sensitivity tests using similar assumptions, for the reasons outlined above and following discussion with referees, it adopted assumptions for its reference scenario which it considered more plausible. The modelled economy-wide gains are buttressed by a number of other considerations.

On balance, therefore, the Commission concluded that reducing automotive assistance as scheduled could be expected to have a positive pay off for the Australian community. In our assessment, Dixon's arguments do not overturn this. Even if his assumptions and conclusions were considered to be closer to the mark, it would seem preferable to implement interventions that targeted the source of market power than to keep car prices high for all domestic users. 


\section{References}

ABS (2008), Australian National Accounts: National Income, Expenditure and Product, September 2008, Analysis and Comments, ABS Cat. No. 5206.0.

Adams, P., Horridge, M. and Wittwer, G. (2002) A Dynamic Multi-Regional Applied General Equilibrium Model of the Australian Economy, Draft documentation prepared for the Regional GE Modelling Course, Centre of Policy Studies, Monash University, 25-29 November.

CIE (Centre for International Economics) (2002) Modelling International Developments: GTAP Simulations of PMV and Other Tariff Changes, Report prepared for the Productivity Commission.

Coleman, W. (2008) "Gauging economic performance under changing terms of trade: real gross domestic income or real gross domestic product?", Economic Papers, 27:4, pp. 329-42.

Dixon, P.B. (2008) Comments on the Productivity Commission's Modelling of the Economy-wide Effects of Future Automotive Assistance, Centre of Policy Studies, Monash University.

and Rimmer, M.T. (2008) Welfare Effects of Unilateral Changes in Tariffs on Motor Vehicles and Parts, Report commissioned by Lateral Economics, Centre of Policy Studies, Monash University.

LE (Lateral Economics) (2008) Should We Cut Automotive Tariffs?, Melbourne.

Murphy, C. (2002) A Guide to Econtech's Industry Model - Murphy Model 600 plus (MM600+), Econtech.

PC (2008a) Modelling the Economy-wide Effects of Future Automotive Assistance, Melbourne.

— (2008b) Modelling the Economy-wide Effects of Future Automotive Assistance, Technical supplement, Melbourne.

— (2008c) Modelling the Economy-wide Effects of Future Automotive Assistance: Measuring Welfare, Technical supplement, Melbourne.

- (2003) Review of Automotive Assistance, Report No. 25, Canberra. 